\title{
BH3-only proteins in control: specificity regulates MCL-1 and BAK-mediated apoptosis
}

\author{
Céline Gélinas ${ }^{1,3,4}$ and Eileen White $\mathrm{e}^{1,2,4,5}$ \\ ${ }^{1}$ Center for Advanced Biotechnology and Medicine, ${ }^{2}$ Howard Hughes Medical Institute, Department of Molecular Biology \\ and Biochemistry, Rutgers University, Piscataway, New Jersey 08854, USA; ${ }^{3}$ Department of Biochemistry, University of \\ Medicine and Dentistry of New Jersey, Piscataway, New Jersey 08854, USA; ${ }^{4}$ Cancer Institute of New Jersey, \\ New Brunswick, New Jersey 08901, USA
}

The BCL-2 family of proteins regulates apoptosis, and proper control of this process is required for normal development and for preventing disease (Adams 2003; Danial and Korsmeyer 2004). After years of identifying components and deciphering the regulatory pathways that control apoptosis, we are now at the point of exploiting this knowledge in sophisticated ways for therapeutic intervention in disease conditions such as cancer. Members of the BCL-2 family fall into three different classes of proteins based on conservation of BCL-2 homology (BH1-4) domains: multidomain anti-apoptotic proteins (BCL-2, BCL- $\mathrm{x}_{\mathrm{L}}, \mathrm{MCL}-1, \mathrm{BCL}-\mathrm{w}$, and BFL-1/A1), multidomain proapoptotic proteins (BAX and $\mathrm{BAK})$, and BH3-only proapoptotic proteins (BID, BAD, BIM, PUMA, NOXA, HRK, BMF, and NBK/BIK). The proapoptotic $\mathrm{BH} 3$-only proteins are the most apical regulators of this death-signaling cascade, and are activated by multiple stimuli from inside or outside the cell to initiate the apoptotic response. They are regulated transcriptionally, and by post-translational modifications such as phosphorylation, ubiquitination, and proteolytic cleavage (Puthalakath and Strasser 2002). Their BH3 domain is an amphipathic $\alpha$-helix that serves as a binding motif for interaction with a hydrophobic groove on either multidomain anti- or proapoptotic BCL-2 family members. This BH3 domain-mediated interaction of $\mathrm{BH} 3$-only proteins with multidomain BCL-2 family proteins either antagonizes the survival activity of anti-apoptotic proteins or activates proapoptotic BAX and BAK. Evidence suggests that antagonism of survival functions cooperates with activation of BAX or BAK for cell death /Cheng et al. 2001; Letai et al. 2002; Chen et al. 2005; Kuwana et al. 2005). It is clear that BH3-only proteins function upstream of BAX and BAK, which are for the most part functionally redundant and required for apoptosis: Deficiency in BAX and BAK renders the proapoptotic func-

${ }^{5}$ Corresponding author.

E-MAIL ewhite@cabm.rutgers.edu; FAX (732) 235-5795.

Article and publication are at http://www.genesdev.org/cgi/doi/10.1101/ gad.1326205. tion of BH3-only proteins inactive and confers resistance to apoptosis induced by many diverse stimuli (Lindsten et al. 2000; Wei et al. 2001; Zong et al. 2001; Degenhardt et al. 2002a,b). Significant issues being addressed include how the multidomain anti-apoptotic proteins act to control proapoptotic proteins, how toxic BAX and BAK are kept in check in healthy cells, and the targets and specificity of the multiple $\mathrm{BH} 3$-only proteins. Willis et al. (2005) provide insight into the specificity of BH3-only proteins by showing that BAK is activated through its NOXA-dependent displacement from MCL-1, and that coordinate inactivation of $\mathrm{BCL}-\mathrm{x}_{\mathrm{L}}$ by other $\mathrm{BH} 3$-only proteins is required for cell death. Thus, the binding specificity of the $\mathrm{BH} 3$ domains of $\mathrm{BH} 3$-only proteins for particular multidomain proapoptotic and anti-apoptotic BCl-2 family members can reveal important aspects of the regulation of cell death. Understanding this regulation and its specificity is essential for developing therapeutics for diseases where apoptosis control is aberrant, such as cancer.

\section{It's all about protein conformation}

Multidomain BCL-2 family members possess a bundle of amphipathic $\alpha$-helices and can exist in different conformations that directly relate to their function. These conformational states, designated here as inactive $(\mathrm{I})$, ligand $(\mathrm{L})$, receptor $(\mathrm{R})$, or oligomer $(\mathrm{O})$, are determined by the availability of a $\mathrm{BH} 3$ domain and the mode of interaction with other BCL-2 family members. BAX ${ }^{\mathrm{I}}$, for example, has a hydrophobic groove that could serve as a receptor for a $\mathrm{BH} 3$, but the groove is occluded by the C-terminal $\alpha$-helical putative transmembrane domain (Suzuki et al. 2000). Consequently, BAX ${ }^{\mathrm{I}}$ is a latent monomer that resides in the cytoplasm. Apoptotic stimuli that activate BAX induce a profound change in its conformation, revealed by altered epitope availability and its ability to form homodimers and oligomers (Adams 2003; Danial and Korsmeyer 2004). Furthermore, this altered state is associated with membrane translocation. Binding and structural data suggest that the exposed $\mathrm{BH} 3$ in $\mathrm{BAX}^{\mathrm{L}}$ has 
the potential to interact with a hydrophobic groove in $\mathrm{BAX}^{\mathrm{R}}$ made available by the release of the $\mathrm{C}$ terminus from the binding groove. Oligomerization may be accomplished by domain swapping between $\mathrm{R}$ and $\mathrm{L}$ conformers and is associated with the permeabilization of organelle membranes, particularly those of mitochondria, to propagate apoptotic signaling. This conformational activation of BAX can be initiated by the interaction of $\mathrm{BAX}^{\mathrm{I}}$ with the caspase-8-cleaved and activated form of BID - designated truncated $(\mathrm{t}) \mathrm{BID}$ or $\mathrm{BID}^{\mathrm{L}}$ - by a hit-and-run mechanism to propagate formation of $\mathrm{BAX}^{\mathrm{O}}$, and BAK may be similarly activated (Fig. 1; Perez and White 2000; Wei et al. 2000; Kuwana et al. 2005). The multidomain anti-apoptotic BCL-2 family members may thwart the activation of multidomain proapoptotic proteins by acting as $\mathrm{R}$ conformer sinks for the $\mathrm{BH} 3 \mathrm{~s}$ of $\mathrm{BID}^{\mathrm{L}}$ and similar proteins, thereby preventing apoptosis (Cheng et al. 2001; Letai et al. 2002). Alternatively, BH3only proteins in the L conformation may overwhelm the $\mathrm{R}$ conformers of the multidomain anti-apoptotic BCL-2 family members, thereby driving forward the death process. In another tier of regulation, activated $\mathrm{BAX}^{\mathrm{L}}$ and $\mathrm{BAK}^{\mathrm{L}}$ can still be inhibited by binding to multidomain anti-apoptotic BCL-2 family members, as illustrated by the viral homolog of BCL-2, E1B 19K. E1B 19K has no counterpart to the C-terminal $\alpha$-helix of other multidomain family members to potentially occlude its BH3binding pocket, and binding data suggest that it is constitutively in the $\mathrm{R}$ conformation and specifically binds $\mathrm{BAX}^{\mathrm{L}}$ and $\mathrm{BAK}^{\mathrm{L}} \mathrm{BH} 3 \mathrm{~s}$ (Cuconati and White 2002; Cuconati et al. 2003). The specificity of $\mathrm{E} 1 \mathrm{~B} 19 \mathrm{~K}^{\mathrm{R}}$ for $\mathrm{BAX}{ }^{\mathrm{L}}$ and $\mathrm{BAK}^{\mathrm{L}}$ renders it an effective apoptosis inhibitor sub-

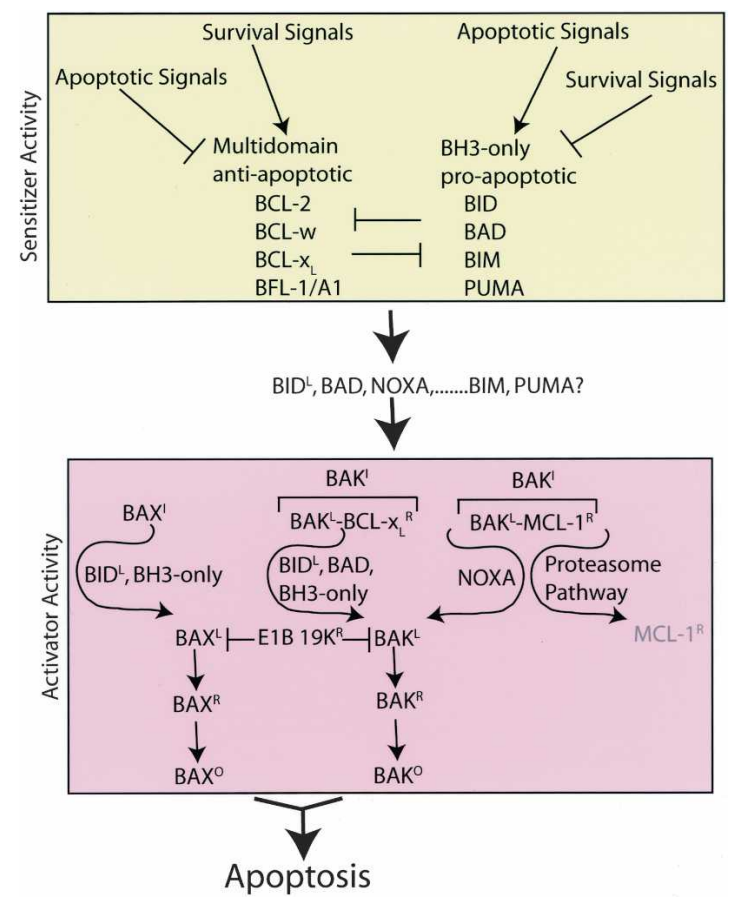

Figure 1. Levels of apoptosis regulation by BCL-2 family members. See text for explanation. sequent to BAX and BAK activation at the choke point for death signaling via a multitude of pathways, accounting for its robust anti-apoptotic activity (Cuconati and White 2002; Nelson et al. 2004). Whether cellular antiapoptotic BCL-2 family members can function analogously downstream of BAX and BAK activation has not been definitively determined. Furthermore, although the regulation of BAX conformation and function has emerged, the regulation of BAK has been substantially less clear.

\section{Who's got your BAK?}

In contrast to monomeric $\mathrm{BAX}^{\mathrm{I}}, 24-\mathrm{kDa} \mathrm{BAK}$ is found in a $60-70-k D a$ membrane-bound protein complex not detectably interacting with itself in healthy cells (Sundararajan et al. 2001), suggesting that the mechanism keeping BAK inactive is distinctly different from that of BAX. The presumption at the time was that another anti-apoptotic cellular protein might maintain BAK in an inactive state, and the hunt was on to identify the BAK chaperone. The mitochondrial protein VDAC2 associates with BAK in healthy mitochondria; however, the ability of VDAC2 to restrain BAK activation by apoptotic stimuli is limited, and is insufficient to explain the regulation of BAK in cytoplasmic membranes independent of mitochondria (Cheng et al. 2003). More interestingly, the cytoplasmic membrane-associated antiapoptotic multidomain $45-\mathrm{kDa}$ MCL-1 coimmunoprecipitates with BAK in healthy cells, suggesting that in contrast to BAX, BAK may be kept inactive by interaction with a multidomain anti-apoptotic BCL-2 family member in organelle membranes (Cuconati et al. 2003).

\section{MCL-1 keeps BAK on a leash}

The BAK-MCL-1 association in healthy cells suggests that in contrast to BAX, which is kept inactive by virtue of its conformational state, MCL-1 may sequester BAK in an inactive protein complex (Cuconati et al. 2003). Indeed, the presence of an apoptotic stimulus such as DNA damage mediated by UV irradiation or oncogene activation causes the elimination of MCL-1 by targeting it for degradation in proteasomes, thereby unleashing BAK and promoting apoptosis (Cuconati et al. 2003; Nijhawan et al. 2003). Restoration of MCL-1 completely blocks DNA damage response-mediated apoptosis, demonstrating that MCL-1 elimination is essential for cell death in this pathway. This destruction of MCL-1, although required, is not sufficient in itself to trigger apoptosis, indicating that although MCL-1 maintains BAK in an inactive state, an additional activity is required for cell death (Cuconati et al. 2003; Nijhawan et al. 2003). This activity could result from the necessity of a second step to activate BAK, such as a BH3-only protein interaction, or that there is another anti-apoptotic protein that is functionally redundant with MCL-1. Interestingly, disruption of the BAK-MCL-1 complex is also associated with p53-dependent, transcription-independent apoptosis, suggesting that it may be a common event in 
other apoptotic pathways (Leu et al. 2004). Dissociation of the MCL-1-BAK complex appears to precede MCL-1 elimination, suggesting that ubiquitin-mediated degradation of MCL-1 occurs subsequent to the release of BAK (Cuconati et al. 2003). It is not clear, however, what the conformational state of $\mathrm{BAK}$ is when complexed to MCL-1. Unlike BAX ${ }^{\mathrm{I}}, \mathrm{BAK}^{\mathrm{I}}$ may consist of $\mathrm{BAK}^{\mathrm{L}}$ bound to $\mathrm{MCL}-1^{\mathrm{R}}$, much in the way $\mathrm{E} 1 \mathrm{~B} 19 \mathrm{~K}^{\mathrm{R}}$ binds to and inhibits $\mathrm{BAK}^{\mathrm{L}}$ after it is released from MCL-1 (Cuconati et al. 2003). Indeed, the BAK BH3 binds with high affinity to MCL-1 (Willis et al. 2005) in its hydrophobic groove (Day et al. 2005). In this regard, the structure of BAK bound to MCL-1 or E1B 19K may be informative. What is missing from this scenario is the trigger for MCL-1 to release BAK, the mechanism of MCL-1 degradation, and the identity of the second step required for activation of BAK and apoptosis.

\section{Who's doing what to whom?}

One approach to deciphering the myriad of possible protein-protein interactions among BCL-2 family members is to decode the binding specificity of the $\mathrm{BH} 3$ domains for multidomain grooves. Given the number of BCL-2 family members involved and the number of potential combinations of $\mathrm{BH} 3$-groove interactions, this has been determined systematically by examining the interaction of different $\mathrm{BH} 3$ peptides with multidomain grooves using in vitro biosensor, competitive binding, and functional assays (Cheng et al. 2001; Letai et al. 2002; Chen et al. 2005; Kuwana et al. 2005). It has been made clear that $\mathrm{BH} 3 \mathrm{~s}$ have distinct specificities for grooves, in experiments that have been validated by in vivo interactions and function, and with structural studies in some cases. What emerged are clear differences between the binding preferences of $\mathrm{BH} 3 \mathrm{~s}$ for different multidomain grooves that may explain important aspects of regulation of apoptosis: Some BH3s were highly specific while others were not.

\section{BH3-only proteins reveal their specificity}

Among the least specific $\mathrm{BH} 3$ s are those of the $\mathrm{BH} 3$-only proteins BIM and PUMA, which can bind the grooves of all of the multidomain anti-apoptotic BCL-2 family members tested (Letai et al. 2002; Chen et al. 2005). In contrast, the $\mathrm{BH} 3$ of NOXA is highly specific for MCL-1 and BFL-1/A1. The BH3s of BID and BIM were also capable of binding the grooves of multidomain BAK and BAK and promoting their oligomerization, whereas other $\mathrm{BH} 3 \mathrm{~s}$ such as that of BAD appeared more exclusive for binding to multidomain anti-apoptotic proteins such as BCL-2 and BCL- $\mathrm{x}_{\mathrm{L}}$ (Cheng et al. 2001; Chen et al. 2005). This collective type of data led to the notion of discrete roles for $\mathrm{BH} 3$-only protein interactions governed by the binding specificity of their $\mathrm{BH} 3 \mathrm{~s}$ for multidomain grooves. These interactions can be divided into two categories: the sensitizers of multidomain anti-apoptotic proteins, and the activators of multidomain proapoptotic BAX and BAK (Fig. 1). We can now appreciate that there exists fine control of binding specificity among the sensitizers and activators. The requirement for coordinate activator and sensitizer activities to achieve apoptosis is indicated by functional studies in vitro and in vivo (Cheng et al. 2001; Letai et al. 2002; Chen et al. 2005; Kuwana et al. 2005). This has significant implications for cancer therapy, as inhibiting BCL-2 (sensitizer activity), for example, may have to be coordinated with activation of BAX and/or BAK (activator activity) (Fig. 1). Accordingly, the apparent dual role of some $\mathrm{BH}$-only proteins in potentially mediating activator and sensitizer activity may render their function more important in tumor suppression.

\section{NOXA targets MCL-1, unleashing BAK}

The fairly specific binding preference of the NOXA BH3 for MCL-1 suggests that NOXA may be a factor that releases BAK. Willis et al. (2005) tested this hypothesis and found it to be the case: Overexpressed NOXA displaces BAK from MCL-1 and promotes MCL-1 degradation in proteasomes, and this activity is dependent on the ability of the NOXA BH3 to bind MCL-1. Furthermore, NOXA deficiency produces elevated MCL-1 levels and impairs NOXA-mediated MCL-1 turnover in response to DNA damage (Willis et al. 2005). Perhaps the binding of BAK to MCL-1 sterically inhibits its ubiquitination, or the release of BAK provokes a conformational change or formation of an alternate protein complex that facilitates ubiquitination and degradation of MCL-1. This, however, is not sufficient for cell death, nor is the elimination of MCL-1 by RNAi (Cuconati et al. 2003; Nijhawan et al. 2003), suggesting the existence of a second step, perhaps another MCL-1-like activity. Nonetheless, identification of the steps required for degradation of MCL-1 and the ubiquitin ligase involved in its proteasome-mediated degradation will be important for therapeutically poising cancer cells on the threshold of cell death. In light of the crucial role of MCL-1 in embryogenesis (Rinkenberger et al. 2000), in Band T-cell development (Opferman et al. 2003), and in the myeloid lineage (Opferman et al. 2005), it will also be interesting to see how developmental cues affect MCL-1 stability. Phosphorylated BIM, NBK/BIK, and BFL-1/A1 are known to undergo proteasome-mediated degradation (Marshansky et al. 2001; Akiyama et al. 2003; Ley et al. 2003; Luciano et al. 2003; Kucharczak et al. 2005; Zhu et al. 2005), but whether they are regulated similarly to MCL-1 remains to be determined. It is worth noting that despite the fact that the $\mathrm{BH} 3$ of NOXA interacts selectively with both MCL-1 and BFL-1/A1, evidence is still lacking for a BFL-1/A1-BAK interaction (Werner et al. 2002; Willis et al. 2005), nor has a NOXA-BFL-1/A1 association been reported. Given the similar binding specificity of MCL-1 and BFL-1/A1 for the NOXA BH3, it may be worth evaluating the interactions between these proteins in intact cells. 


\section{BCL- $x_{L}$ picks up the slack and has your BAK}

The mystery as to why MCL-1 elimination is not sufficient for cell death was revealed with the discovery that the BAK BH3 also binds the groove of BCL- $\mathrm{X}_{\mathrm{L}}$ (Sattler et al. 1997) and has high affinity for BCL- $\mathrm{X}_{\mathrm{L}}$ (Willis et al. 2005). Furthermore, BAK is bound to $B C L-x_{L}$ and to MCL-1 in healthy cells, and liberation of BAK from both MCL-1 and BCL- $\mathrm{X}_{\mathrm{L}}$ is required for apoptosis (Willis et al. 2005). As NOXA does not bind BCL- $x_{L}$, this indicates that another $\mathrm{BCL}-\mathrm{x}_{\mathrm{L}}$-specific $\mathrm{BH} 3$-only protein is required for activation of the BAK-BCL- $\mathrm{x}_{\mathrm{L}}$ axis (Fig. 1). Fusion of the BAD BH3 to $\mathrm{BIM}_{\mathrm{S}}$, which can bind $\mathrm{BCL}-\mathrm{x}_{\mathrm{L}}$ but not MCL-1, cooperates with NOXA to induce apoptosis, as does a NOXA mutant with a $\mathrm{BH} 3$ engineered to bind both MCL-1 and BCL- $\mathrm{x}_{\mathrm{L}}$. Finally, NOXA kills BCL$\mathrm{x}_{\mathrm{L}}$-deficient but not wild-type cells, providing support for the dual sequestration model for BAK. Thus, coordinate regulation of the BAK-MCL-1 axis and the BAK$\mathrm{BCL}-\mathrm{x}_{\mathrm{L}}$ axis may be required for efficient therapeutic modulation of apoptosis.

\section{Consequences for therapeutic modulation of apoptosis}

Understanding the specificities of endogenous $\mathrm{BH} 3$ interactions in intact cells will be essential for developing effective therapeutics targeting the apoptotic response. The situation may be more complex in various disease states, such as cancer where apoptosis is often altered, or if tissue-specific expression or regulation of various BCL-2 family member is significant. Establishing the basic principles by which the BCL-2 family is regulated, particularly deciphering the binding code that governs their interactions with each other, is an important first step. As BCL-2 is up-regulated in some human cancers (Cory et al. 2003), the identification of a process that can bypass BCL-2 through specific $\mathrm{BH} 3$-only protein-mediated activation of BAK to induce apoptosis is important. MCL-1 has been implicated in the promotion of lymphomagenesis (Zhou et al. 2001), while bcl-x and bfl-1/ a1 are transcriptional targets of the NF-кB family, many members of which are notoriously oncogenic (Karin et al. 2002; Kucharczak et al. 2003). Thus effective therapies may rely on defeating the function of anti-apoptotic BCL-2 family members and this acquired resistance to apoptosis. Understanding the function, mode of interaction, and the regulation of these important proteins takes us one step closer to this goal of activating apoptosis in tumor cells with acquired resistance. Similarly, the loss of function of proapoptotic BCL-2 family members contributes to oncogenesis (Degenhardt et al. 2002a; Ranger et al. 2003; Zinkel et al. 2003; Egle et al. 2004; Hemann et al. 2004; Tan et al. 2005). Identifying alternate means for reactivation of death programs to bypass these defects requires a blueprint of the signaling pathways in which they participate and their mechanisms of regulation.

\section{Looking upstream of BAK}

In this regard it is interesting to note that while NF- $\mathrm{KB}$ is generally anti-apoptotic, it can sensitize cells to apopto- sis in response to particular death-inducing stimuli in certain cells (Kucharczak et al. 2003; Perkins 2004). The anti-apoptotic versus proapoptotic effects of NF- $\kappa \mathrm{B}$ in response to certain DNA damage-inducing stimuli may converge, at least in part, on its ability to regulate $b c l-x$ gene expression. Indeed, recent studies showed that some stimuli that induce DNA damage inhibit NF-кBdependent transactivation of anti-apoptotic genes such as $b c l-x$ by promoting the association of RELA with histone deacetylases, thereby facilitating cell death (Campbell et al. 2004). Conversely, attenuation of the apoptotic response to lower amounts of UVC-induced DNA damage (Kato et al. 2003) may derive from the ability of NF$\kappa \mathrm{B}$ to induce $b c l-x$ transcription. Although MCL- 1 has not been reported to be an NF- $\kappa \mathrm{B}$ target, its expression is regulated by the mitogen-activated protein (MAP) kinase, PI-3 kinase, and JAK/STAT pathways (Michels et al. 2004) with similarly prominent roles in oncogenesis. It is tempting to speculate that $\mathrm{BCL}-\mathrm{x}_{\mathrm{L}}$ plays a central role in NF-кB-mediated survival in response to certain DNA damaging stimuli by suppressing BAK activation. The dual ability of BAK to be sequestered by MCL-1 and $\mathrm{BCL}-\mathrm{x}_{\mathrm{L}}$, and their independent modes of regulation, reveal that defeating survival signaling in cancer may be best accomplished through inhibition of both mechanisms of BAK sequestration.

\section{Details are important}

Many known cancer therapeutics work either directly or indirectly, in all or in part, through the activation of apoptosis. Newer targeted therapeutics directed against specific activating mutational events in particular cancers, affecting kinases for example, cause tumor cell apoptosis, presumably through inhibition of survival signaling pathways. A new class of cancer therapeutics represented by Velcade (bortezomib, PS-341) targets the proteasome, which may prevent NF-кB-mediated antiapoptotic function by blocking proteasome-mediated degradation of the NF-кB inhibitor IкB (Rajkumar et al. 2005). The ubiquitin proteasome pathway also regulates the proapoptotic BH3-only protein BIM, where activation of the MAP kinase pathway phosphorylates BIM, thereby promoting its destruction (Akiyama et al. 2003; Ley et al. 2003; Luciano et al. 2003). BIM elimination by MAP kinase pathway activation in tumors renders them refractory to chemotherapy by taxanes, which require BIM for apoptosis, and coadministration of Velcade restores BIM accumulation to enable tumor regression (Tan et al. 2005). One puzzle in this scenario is the specificity of Velcade for re-enabling BIM-mediated tumor apoptosis, where Velcade could have easily instead promoted accumulation of MCL-1 and tumor survival. We now know that both MCL-1 and BCL- $\mathrm{x}_{\mathrm{L}}$ can sequester BAK (Willis et al. 2005), but in the presence of an apoptotic stimulus, only MCL-1 is targeted for proteasomemediated degradation, whereas BCL- $\mathrm{x}_{\mathrm{L}}$ instead translocates to mitochondria (Nijhawan et al. 2003) where it can associate with BAK. The functional redundancy of these two anti-apoptotic proteins, only one of which is 
regulated by the proteasome, may limit the impact of a proteasome inhibitor on this step of apoptotic signaling. Alternativley, the $\mathrm{BH} 3$ of BIM, in stark contrast to that of NOXA, is broadly specific for many BCL-2 family members (Letai et al. 2002; Chen et al. 2005; Willis et al. 2005). Thus, inhibiting BIM degradation with Velcade may be the dominant activity in directing the proapoptotic response to taxane-mediated chemotherapy. Thus, understanding the fundamentals of apoptosis regulation, deciphering how apoptotic pathways are altered in human cancers, and establishing the means by which therapeutics work to activate apoptosis are all important for linking tumor genotype to a rational approach to combination chemotherapy.

\section{Acknowledgments}

We thank Dr. Kurt Degenhardt, Ting-Ting Tan, and Mathew Simmons for critical reading of the manuscript.

\section{References}

Adams, J.M. 2003. Ways of dying: Multiple pathways to apoptosis. Genes \& Dev. 17: 2481-2495.

Akiyama, T., Bouillet, P., Miyazaki, T., Kadono, Y., Chikuda, H., Chung, U.-I., Fukuda, A., Hikita, A., Seto, H., Okada, T., et al. 2003. Regulation of osteoclast apoptosis by ubiquitylation of proapoptotic BH3-only Bcl-2 family member Bim. EMBO J. 22: 6653-6664.

Campbell, K.J., Rocha, S., and Perkins, N.D. 2004. Active repression of antiapoptotic gene expression by RelA(p65) NF-к B. Mol. Cell 13: 853-865.

Chen, L., Willis, S.N., Wei, A., Smith, B.J., Fletcher, J.I., Hinds, M.G., Colman, P.M., Day, C.L., Adams, J.M., and Huang, D.C.S. 2005. Differential targeting of prosurvival Bcl-2 proteins by their BH3-only ligands allows complementary apoptotic function. Mol. Cell 17: 393-403.

Cheng, E., Wei, M., Weiler, S., Flavell, R., Mak, T., Lindsten, T., and Korsmeyer, S. 2001. BCL-2, BCL- $\mathrm{X}_{\mathrm{L}}$ sequester BH3 domain-only molecules preventing BAX- and BAK-mediated mitochondrial apoptosis. Mol. Cell 8: 705-711.

Cheng, E.H., Sheiko, T.V., Fisher, J.K., Craigen, W.J., and Korsmeyer, S.J. 2003. VDAC2 inhibits BAK activation and mitochondrial apoptosis. Science 301: 513-517.

Cory, S., Huang, D.C., and Adams, J.M. 2003. The Bcl-2 family: Roles in cell survival and oncogenesis. Oncogene 22: 85908607.

Cuconati, A. and White, E. 2002. Viral homologues of Bcl-2: Role of apoptosis in the regulation of virus infection. Genes \& Dev. 16: 2465-2478.

Cuconati, A., Mukherjee, C., Perez, D., and White, E. 2003. DNA damage response and MCL-1 destruction initiate apoptosis in adenovirus-infected cells. Genes \& Dev. 17: 29222932.

Danial, N.N. and Korsmeyer, S.J. 2004. Cell death: Critical control points. Cell 116: 205-219.

Day, C.L., Chen, L., Richardson, S.J., Harrison, P.J., Huang, D.C.S., and Hind, M.G. 2005. Solution structure of prosurvival Mcl-1 and characterization of its binding by proapoptotic BH3-only ligands. J. Biol. Chem. 280: 4738-4744.

Degenhardt, K., Chen, G., Lindsten, T., and White, E. 2002a. Bax and Bak mediate p53-independent suppression of tumorigenesis. Cancer Cell 2: 193-203.
Degenhardt, K., Sundararajan, R., Lindsten, T., Thompson, C.B., and White, E. 2002b. Bax and Bak independently promote cytochrome-c release from mitochondria. J. Biol. Chem. 277: 14127-14134.

Egle, A., Harris, A.L., Bouillet, P., and Cory, S. 2004. Bim is a suppressor of Myc-induced mouse B cell leukemia. Proc. Natl. Acad. Sci. 101: 6164-6169.

Hemann, M.T., Zilfou, J.T., Zhao, Z., Bugess, D.J., Hannon, G.J., and Lowe, S.W. 2004. Suppression of tumorigenesis by the p53 target PUMA. Proc. Natl. Acad. Sci. 101: 9333-9338.

Kato Jr., T., Delhase, M., Hoffmann, A., and Karin, M. 2003. CK2 is a C-terminal IкB kinase responsible for NF-кB activation during the UV response. Mol. Cell 12: 829-839.

Karin, M., Cao, Y., Greten, F.R., and Li, Z.W. 2002. NF-кB in cancer: From innocent bystander to major culprit. Nat. Rev. Cancer 2: 301-310.

Kucharczak, J., Simmons, M.J., Fan, Y., and Gelinas, C. 2003. To be, or not to be: NF- $\kappa$ B is the answer-Role of Rel/NF- $\mathrm{BB}$ in the regulation of apoptosis. Oncogene 22: 8961-8982.

Kucharczak, J.F., Simmons, M.J., Duckett, C.S., and Gelinas, C. 2005. Constitutive proteasome-mediated turnover of Bfl-1/ $\mathrm{A} 1$ and its processing in response to TNF receptor activation in FL5-12 pro-B cells convert it into a pro-death factor. Cell. Death Differ. (in press).

Kuwana, T., Bouchier-Hayes, L., Chipuk, J.E., Bonzon, C., Sullivan, B.A., Green, D.R., and Newmeyer, D.D. 2005. BH3 domains of $\mathrm{BH} 3$-only proteins differentially regulate baxmediated mitochondrial membrane permeabilization both directly and indirectly. Mol. Cell 17: 525-535.

Letai, A., Bassik, M.C., Walensky, L.D., Sorcinelli, M.D., Weiler, S., and Korsmeyer, S.J. 2002. Distinct BH3 domains either sensitize or activate mitochondrial apoptosis, serving as prototype cancer therapeutics. Cancer Cell 2: 183-192.

Leu, J.I., Dumont, P., Hafey, M., Murphy, M.E., and George, D.L. 2004. Mitochondrial p53 activates Bak and causes disruption of a Bak-Mcl1 complex. Nat. Cell Biol. 6: 443-450.

Ley, R., Balmanno, K., Hadfield, K., Weston, C., and Cook, S.J. 2003. Activation of the ERK1/2 signaling pathway promotes phosphorylation and proteasome-dependent degradation of the BH3-only protein, Bim. J. Biol. Chem. 278: 18811-18816.

Lindsten, T., Ross, A.J., King, A., Zong, W.-X., Rathmell, J.C., Shiels, H.A., Ulrich, E., Waymire, K.G., Mahar, P., Frauwirth, K., et al. 2000. The combined functions of the proapoptotic Bcl-2 family members, Bak and Bax, are essential for the normal development of multiple tissues. Mol. Cell 6: 1389-1399.

Luciano, F., Jacquel, A., Colosetti, P., Herrant, M., Cagnol, S., Pages, G., and Auberger, P. 2003. Phosphorylation of Bim-EL by Erk1/2 on serine 69 promotes its degradation via the proteasome pathway and regulates its proapoptotic function. Oncogene 22: 6785-6793.

Marshansky, V., Wang, X., Bertrand, R., Luo, H., Duguid, W., Chinnadurai, G., Kanaan, N., Vu, M.D., and Wu, J. 2001. Proteasomes modulate balance among proapoptotic and antiapoptotic Bcl-2 family members and compromise functioning of the electron transport chain in leukemic cells. J. Immunol. 166: 3130-3142.

Michels, J., Johnson, P.W.M., and Packham, G. 2004. Molecules in focus-Mcl-1. Int. J. Biochem. Cell Biol. 37: 267-271.

Nelson, D.A., Tan, T.-T., Rabson, A.B., Anderson, D., Degenhardt, K., and White, E. 2004. Hypoxia and defective apoptosis drive genomic instability and tumorigenesis. Genes \& Dev. 18: 2095-2107.

Nijhawan, D., Fang, M., Traer, E., Zhong, Q., Gao, W., Du, F., and Wang, X. 2003. Elimination of Mcl-1 is required for the initiation of apoptosis following ultraviolet irradiation. 
Genes \& Dev. 17: 1475-1496.

Opferman, J.T., Letai, A., Beard, C., Sorcinelli, M.D., Ong, C.C., and Korsmeyer, S. 2003. Development and maintenance of B and $\mathrm{T}$ lymphocytes requires antiapoptotic Mcl-1. Nature 426: $671-676$.

Opferman, J.T., Iwasaki, H., Ong, C.C., Suh, H., Mizuno, S.-I., Akashi, K., and Korsmeyer, S. 2005. Obligate role of antiapoptotic MCL-1 in the survival of hematopoietic stem cells. Science 307: 1101-1104.

Perez, D. and White, E. 2000. TNF- $\alpha$ signals apoptosis through a Bid-dependent conformational change in Bax that is inhibited by E1B 19K. Mol. Cell 6: 53-63.

Perkins, N.D. 2004. Regulation of NF-кB by atypical activators and tumour suppressors. Biochem. Soc. Trans. 32: 936-939.

Puthalakath, H. and Strasser, A. 2002. Keeping killers on a tight leash: Transcriptional and post-translational control of the pro-apoptotic activity of BH3-only proteins. Cell Death Differ. 9: 505-512.

Rajkumar, S.V., Richardson, P.G., Hideshima, T., and Anderson, K.C. 2005. Proteasome inhibition as a novel therapeutic target in human cancer. J. Clin. Oncol. 23: 630-639.

Ranger, A.M., Zha, J.P., Harada, H., Datta, S.R., Danial, N.N., Gilmore, A.P., Kutok, J.L., LeBeau, M.M., and Greenberg, M.E. 2003. Bad-deficient mice develop diffuse large B cell lymphoma. Proc. Natl. Acad. Sci. 100: 9324-9329.

Rinkenberger, J.L., Horning, S., Klocke, B., Roth, K., and Korsmeyer, S.J. 2000. Mcl-1 deficiency results in peri-implantation embryonic lethality. Genes \& Dev. 14: 23-27.

Sattler, M., Liang, H., Nettesheim, D., Meadows, R.P., Harlan, J.E., Eberstadt, M., Yoon, H.S., Shuker, S.B., Chang, B.S., Minn, A.J., et al. 1997. Structure of Bcl- $\mathrm{x}_{\mathrm{L}}-\mathrm{Bak}$ peptide complex: Recognition between regulators of apoptosis. Science 275: 983-986.

Sundararajan, R., Cuconati, A., Nelson, D., and White, E. 2001. Tumor Necrosis factor- $\alpha$ induces Bax-Bak interaction and apoptosis, which is inhibited by adenovirus E1B 19K. J. Biol. Chem. 276: 45120-45127.

Suzuki, M., Youle, R.J., and Tjandra, N. 2000. Structure of Bax: Coregulation of dimer formation and intracellular localization. Cell 103: 645-654.

Tan, T.-T., Degenhardt, K., Nelson, D.A., Beaudoin, B., NievesNeira, W., Bouillet, P., Villunger, A., Adams, J.M., and White, E. 2005. Key roles of BIM-driven apoptosis in epithelial tumors and rational chemotherapy. Cancer Cell 7: 227238.

Wei, M., Zong, W.-X., Cheng, E., Lindsten, T., Panoutsakopoulou, V., Ross, A., Roth, K., MacGregor, G., Thompson, C., and Korsmeyer, S. 2001. Proapoptotic Bax and Bak: A requisite gateway to mitochondrial dysfunction and death. Science 292: 727-730.

Wei, M.C., Lindsten, T., Mootha, V.K., Weiler, S., Gross, A., Ashiya, M., Thompson, C.B., and Korsmeyer, S.J. 2000. tBid, a membrane-targeted death ligand, oligomerizes Bak to release cytochrome c. Genes \& Dev. 14: 2060-2071.

Werner, A.B., de Vries, E., Tait, S.W., Bontjer, I., and Borst, J. 2002. Bcl-2 family member Bfl-1/AI sequesters truncated bid to inhibit is collaboration with pro-apoptotic Bak or Bax. J. Biol. Chem. 277: 22781-22788.

Willis, S.N., Chen, L., Dewson, G., Wei, A., Naik, E., Fletcher, J.I., Adams, J.M., and Huang, D.C.S. 2005. Proapoptotic Bak is sequestered by $\mathrm{Mcl}-1$ and $\mathrm{Bcl}-\mathrm{x}_{\mathrm{L}}$, but not Bcl-2, until displaced by BH3-only proteins. Genes \& Dev. (this issue).

Zhou, P., Levy, N.B., Xie, H., Qian, L., and Lee, C.Y. 2001. MCL1 transgenic mice exhibit a high incidence of B-cell lymphoma manifested as a spectrum of histologic subtypes. Blood 97: 3902-3909.
Zhu, H., Zhang, L., Dong, F., Guo, W., Wu, S., Teraishi, F., Davis, J.J., Chiao, P.J., and Fang, B. 2005. Bik/NBK accumulation correlates with apoptosis-induction by bortezomib (PS-341, Velcade) and other proteasome inhibitors. Oncogene (in press).

Zinkel, S.S., Ong, C.C., Ferguson, D.O., Iwasaki, H., Akashi, K., Bronson, R.T., Kutok, J.L., Alt, F.W., and Korsmeyer, S.J. 2003. Proapoptotic BID is required for myeloid homeostasis and tumor suppression. Genes \& Dev. 17: 229-239.

Zong, W.-X., Lindsten, T., Ross, A.J., MacGregor, G.R., and Thompson, C.B. 2001. BH3-only proteins that bind pro-survival Bcl-2 family members fail to induce apoptosis in the absence of Bax and Bak. Genes \& Dev. 15: 1481-1486. 


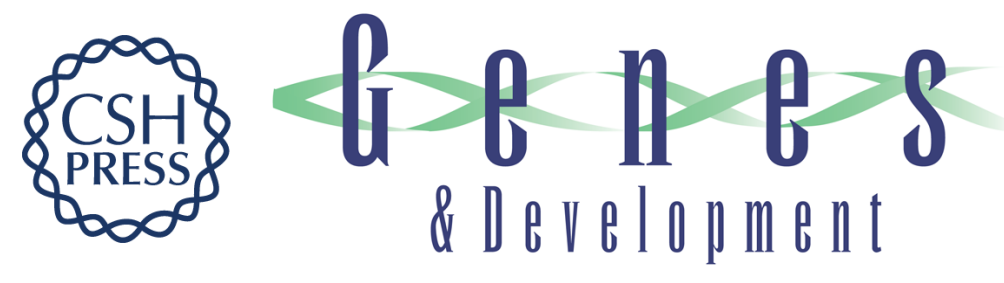

\section{BH3-only proteins in control: specificity regulates MCL-1 and BAK-mediated apoptosis}

Céline Gélinas and Eileen White

Genes Dev. 2005, 19:

Access the most recent version at doi:10.1101/gad.1326205

References This article cites 45 articles, 25 of which can be accessed free at: http://genesdev.cshlp.org/content/19/11/1263.full.html\#ref-list-1

License

Email Alerting

Receive free email alerts when new articles cite this article - sign up in the box at the top Service right corner of the article or click here.

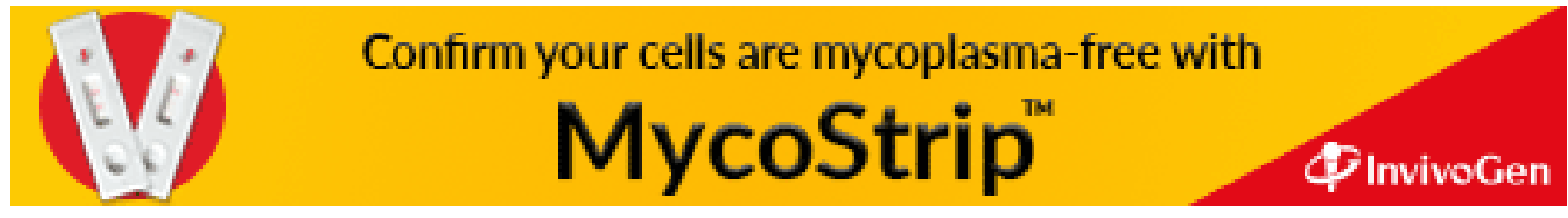

